\title{
Synergistic potential of dillapiole-rich essential oil with synthetic pyrethroid insecticides against fall armyworm
}

\author{
Potencial sinérgico do óleo essencial rico em dilapiol para inseticidas \\ piretroides sintéticos frente à lagarta-do-cartucho
}

\author{
Murilo Fazolin ${ }^{I^{*}}$ Joelma Lima Vidal Estrela ${ }^{\mathrm{I}}$ André Fábio Monteiro Medeiros $^{\mathrm{I}}$ \\ Iriana Maria da Silva ${ }^{I I}$ Luiara Paiva Gomes ${ }^{I I}$ Maria Samylla de Farias Silva ${ }^{I I}$
}

\section{ABSTRACT}

The objective of this study was to evaluate the synergy and response homogeneity of the Spodoptera frugiperda larvae population to the Piper aduncum essential oil in combination with pyrethroid insecticides (alpha-cypermethrin, betacypermethrin, fenpropathrin, and gamma-cyhalothrin) compared to piperonylbutoxide $(P B O)$ as positive control. Synergism (SF comparisons were obtained using lethal concentration $\left(L C_{50}\right)$ and lethal dose $\left(L D_{50}\right)$ ratios of insecticides individually and in their respective synergistic combinations with essential oil and PBO. Dose/concentration-mortality slope curves were used to establish relative toxicity increase promoted by synergism. They also determined homogeneity response. Residual contact revealed significant potentiation for commercial insecticides formulated with beta-cypermethrin $(S F=9.05-0.5)$ and fenpropathrin $(S F=34.05-49.77)$ when combined with the P. aduncum essential oil. For topical contact, significant potentiation occurred only for alpha-cypermethrin ( $S F=7.55-3.68)$, fenpropathrin ( $S F=3.37$ 1.21), and gamma-cyhalothrin ( $S F=5.79-10.48)$ insecticides when combined with essential oil. With the exception of fenpropathrin and gamma-cyhalothrin, insecticides synergistic combinations presented homogeneous response by topical as well as residual contact at least with essential oil. The SF significance values of the $\boldsymbol{P}$ aduncum essential oil combined with alpha-cypermethrin, betacypermethrin, fenpropathrin, and gamma-cyhalothrin insecticides indicated potential for this oil to be used as an alternative to PBO.

Key words: alpha-cypermethrin, beta-cypermethrin, fenpropathrin, gamma-cyhalothrin, insecticide resistance.

RESUMO

O objetivo deste trabalho foi avaliar a sinergia e homogeneidade de resposta de lagartas de Spodoptera frugiperda ao óleo essencial de Piper aduncum, em combinações com inseticidas do grupo dos piretroides: alfa-Cipermetrina,
beta-Cipermetrina, Fenpropatrina e gama-Cialotrina, em comparação ao butóxido de piperonila (PBO controle positivo). Por meio da relação das $C L_{50}$ e $D L_{50}$ dos inseticidas tomados isoladamente e de suas respectivas combinações sinérgicas com o óleo essencial e o PBO, foram obtidos os fatores de sinergismo (FS) para comparação entre si. O coeficiente angular das curvas de dose/concentração-mortalidade foi utilizado no estabelecimento do aumento de toxicidade relativa, promovida pelos sinérgicos e determinação da homogeneidade de resposta. Por contato residual, evidenciou-se significativa potencialização dos inseticidas comerciais formulados com beta-Cipermetrina (FS=9,05-0,5) e Fenpropatrina (FS=34,05-49,77), quando combinados com o óleo essencial de P. aduncum. Já por contato tópico, ocorreu significativa potencialização somente dos inseticidas alfa-Cipermetrina ( $F S=7,55-3,68)$, Fenpropatrina $(F S=3,37-1,21)$ e gama-Cialotrina ( $F S=5,79-10,48)$ quando em combinação com o óleo essencial. Com exceção da Fenpropatrina e gama-Cialotrina, as demais combinações sinérgicas apresentaram homogeneidade de resposta tanto por contato tópico como residual, para pelo menos uma combinação sinérgica com o óleo essencial de $\boldsymbol{P}$. aduncum. A significância dos valores do FS das combinações do óleo essencial de $\boldsymbol{P}$. aduncum com os inseticidas a base de alfa-Cipermetrina, betaCipermetrina, Fenpropatrina e gama-Cialotrina pode indicar que esse óleo essencial é uma alternativa ao $P B O$.

Palavras-chave: alfa-Cipermetrina, beta-Cipermetrina, fenpropatrina, gama-Cialotrina, resistência a inseticidas.

\section{INTRODUCTION}

Synergistic action minimizes the quantity of chemical insecticides necessary to control insects because it acts as an alternative substrate, reacting

\footnotetext{
IEmbrapa Acre, Rodovia BR 364, Km 14, s/n, 69900-056, Rio Branco, AC, Brasil. E-mail: murilo.fazolin@embrapa.br. ${ }^{*}$ Corresponding author.

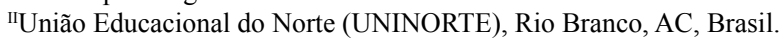


with another site in the enzymatic system, thus preventing insecticide detoxification (CASIDA, 1970). Piperonyl butoxide (PBO) is the synergistic agent most used industrially (ROCHA \& MING, 1999) and had been in commercial formulations of several synthetic pyrethroid insecticides for many years (FARNHAM, 1998). However, PBO has shown acute and chronic toxicity to non-target organisms (WALIA et al., 2004), resulting in reduced interest to use this synergistic agent.

As a possible replacement for $\mathrm{PBO}$, lignans extracted from plants of the Asteraceae and Piperaceae families, which contain a methylenedioxyphenyl group, exhibited synergistic potential for conventional insecticides (BERNARD et al., 1995). Dillapiole rich essential oil, obtained from Piper aduncum L. (Piperaceae), is an alternative to natural production of synergistic lignans on a commercial scale (FAZOLIN et al., 2006). This species, with its variable dillapiole levels (MAIA et al., 1998), is abundant in the western Amazon (PIMENTEL et al., 1998), and is the most promising option to replace PBO (WALIA et al. 2004). Most dillapiole-producing plants; however, have constraints with regard to cultivation at the industrial level, and availability on the market (TOMAR et al., 1979). To further investigate a promising alternative to PBO, this study compared PBO and $\boldsymbol{P}$. aduncum essential oil effects (PAEO) in several insecticide formulations (alpha-cypermethrin, beta-cypermethrin, fenpropathrin, and gamma-cyhalothrin) on the synergy and response homogeneity of Spodoptera frugiperda (J.E. Smith, 1797) larvae.

\section{MATERIALS AND METHODS}

\section{Obtaining $\boldsymbol{P}$, aduncum essential oil}

Adult $P$. aduncum plants were collected from the Embrapa Acre Active Germoplasm Bank $\left(10.0226^{\circ} \mathrm{S}, 67.7088^{\circ} \mathrm{W}\right)$ in February 2013. Plants were cut to $0.4 \mathrm{~m}$ above the soil and their leaves dried in an oven until to $30 \%$ moisture content. Essential oil was extracted via steam distillation using a diesel-heated boiler system, as previously described (PIMENTEL \& SILVA, 2003).

\section{Chromatographic analysis}

Chromatographic analysis of essential oil was performed in a Hewlett Packard (HP) 5890 gas chromatograph (GC) equipped with an Agilent HP-5 fused silica column $(30 \mathrm{~m} \times 0.32 \mathrm{~mm}$ i.d. $\times 0.25 \mu \mathrm{m}$ of film thickness) using helium as the carrier gas at $1 \mathrm{~mL}$ $\mathrm{min}^{-1}$. The GC was additionally coupled with mass spectrometry (GC-MS). Chemical characterization was performed by comparing mass spectra with those available in the mass spectrometry library database of the GC-MS, using authentic standards, data from scientific literature, and Kovats retention indices (ADAMS, 1995). A mixture of linear alkanes (C9 to C26) was injected into the chromatograph to determine the Kovats indices (THOMAZINI \& FRANCO, 2000). Constituents were quantified by GC with a flame ionization detector (GC-FID) under the same operational conditions described for GC-MS.

\section{Toxicology bioassays \\ Insecticide formulations with alpha-} cypermethrin $\left(\right.$ Fastac $^{\circledR} 100$ CS, BASF S.A.), betacypermethrin (Akito ${ }^{\circledR} 100$ CS, Arysta Lifescience Do Brazil Ind.Quim. e Agropecuária Ltda.), fenpropathrin (Danimen ${ }^{\circledR} 300$ EC, Sumitomo Chemical Company Ltda.), and gamma-cyhalothrin (Nexide ${ }^{\circledR} 150 \mathrm{CS}$, Cheminova Brasil Ltda.) were acquired from pesticide stores. The piperonyl butoxide was $90 \%$ technical grade (Sigma Aldrich ${ }^{\circledR}$ ).

Third-instar $\boldsymbol{S}$. frugiperda larvae were used in all experiments, which were conducted at the Embrapa Acre Entomology Laboratory. Individuals were confined in Petri dishes $(5.0 \mathrm{~cm} \times 1.5 \mathrm{~cm})$ and kept in biological oxygen demand (B.O.D) climatic chambers at $25 \pm 2^{\circ} \mathrm{C}$ with a relative humidity of $70 \pm$ $5 \%$ and a 12 -hour photoperiod.

All bioassays used a completely randomized design, with four replicates of each concentration or combination evaluated. Ten larvae isolated in Petri dishes were used as replicates of each treatment, resulting in a total of 40 individuals for each treatment. The different concentrations of essential oils, insecticides, and synergistic combinations were obtained from stock solutions that were diluted in acetone (CORZO et al., 2012).

\section{Preliminary bioassays}

Response ranges corresponding to the dose intervals and levels that resulted in $\boldsymbol{S}$. frugiperda larval mortality were obtained from close to zero to $100 \%$. Narrower response ranges were obtained from this range of doses and levels according to the method described by FINNEY (1971). Seven different concentrations/doses and one control (the acetone used as a solvent) were prepared for the definitive toxicology evaluations.

\section{Statistical analysis}

Mortality values of the treatments were corrected according to the control-induced mortality using the formula by ABBOTT (1925). 
Concentration-mortality curves were determined using Probit analysis in the Statistics Analysis Software (SAS) program (SAS Institute, 2001), which obtained the concentrations $\left(\mathrm{LC}_{50}\right)$ and doses $\left(\mathrm{LD}_{50}\right)$ with a $50 \%$ chance of causing larval mortality for PAEO, insecticides, and synergistic combinations.

Definitive bioassays for topical contact

Initially, $\mathrm{LD}_{50}$ was determined individually

for $\boldsymbol{S}$. frugiperda larvae subjected to treatment with PAEO and each commercial insecticide. Subsequently, combinations of sub-lethal doses of the essential oil (half and a quarter of the $\mathrm{LD}_{50}$ ) and the sub-lethal doses (below $\mathrm{LD}_{40}$ ) of commercial insecticides were prepared to evaluate the synergistic effect.

From each prepared treatment, $1.0 \mu \mathrm{L}$ was applied to the pronotum on the dorsal surface of $\boldsymbol{S}$. frugiperda using a graduated microsyringe (ALSARAR et al., 2006). Insects were fasted while exposed to the treatments for 24 hours. After this period, the mortality of all the individuals was evaluated.

The previously adopted procedure was used to evaluate the combinations of the lethal subdoses of PAEO with insecticides, thus obtaining new doses of synergistic combinations with $50 \%$ chance of larval mortality $\left(\mathrm{LD}_{50}\right)$.

The same insecticide sub-doses used in the essential oil combinations were combined with $\mathrm{PBO}$ in 10:1 (PBO: insecticide) ratio (STEWART, 1998) for a comparison with the synergistic effects of the PAEO.

The synergism factor (SF) was calculated based on GUEDES et al. (1995) using the following equation: $\mathrm{SF}=\mathrm{LD}_{50}$ of the insecticide $/ \mathrm{LD}_{50}$ of the insecticide + PAEO or PBO). The synergistic effect of the PAEO was considered significant when the SF values and their respective confidence intervals (CIs), calculated for each combination of a given insecticide, were greater than or equal to the SF and $\mathrm{CI}$ values obtained for the combination of the same insecticide with $\mathrm{PBO}$.

The angular coefficient of the concentrationmortality curves was used to establish the increase in relative toxicity promoted by the PAEO and PBO. Higher angular coefficients indicated lower phenotypic variation in the insect population's response to these compounds (CHILCUTT \&TABASHNIK, 1995).

\section{Definitive bioassays for residual contact}

From each treatment, $0.2 \mathrm{~mL}$ was applied to $5-\mathrm{cm}$ wide filter paper for the residual contact evaluations. After drying under an exhaust hood, the filter paper was placed into Petri dishes, each of which received one $\boldsymbol{S}$. frugiperda larva. Other methodological procedures adopted were the same as those used in the topical contact bioassays.

\section{RESULTS}

Dillapiole was the major component of the PAEO at $71.9 \%$ (Table 1 ).

PAEO toxicity to the $\boldsymbol{S}$. frugiperda larvae, evaluated by residual and topical contact, can be expressed by an $\mathrm{LD}_{50}$ of $1.2 \times 10^{-2} \mu \mathrm{L} \mathrm{mg} \mathrm{insect}{ }^{-1}$ and an $\mathrm{LC}_{50}$ of $1.1 \times 10^{-4} \mu \mathrm{L} \mathrm{cm}^{-2}$ (Table 2). These lethality values defined the following sub-doses for the synergistic combinations with the insecticides: $5.5 \times 10^{-}$ ${ }^{5} \mu \mathrm{L} \mathrm{cm}^{-2}\left(1 / 2 \mathrm{LC}_{50}\right.$ PAEO $)$ and $2.8 \times 10^{-5} \mu \mathrm{L} \mathrm{cm}^{-2}\left(1 / 4 \mathrm{LC}_{50}\right.$ PAEO) for residual contact evaluations and $6 \times 10^{-3} \mu \mathrm{L}$ $\mathrm{mg}$ insect $^{-1}\left(1 / 2 \mathrm{LD}_{50}\right.$ PAEO) and $3 \times 10^{-3} \mu \mathrm{L} \mathrm{mg} \mathrm{insect}{ }^{-1}$ $\left(1 / 4 \mathrm{LD}_{50}\right.$ PAEO) for topical contact evaluations.

All insecticides in PAEO combinations exhibited toxicity to the $\boldsymbol{S}$. frugiperda larvae via topical contact (Table 2). The SF values caused by PAEO were significant when the PAEO was combined in doses equivalent to $1 / 2$ and $1 / 4$ of the $\mathrm{LD}_{50}$ with the alpha-cypermethrin ( $\mathrm{SF}=7.55$ and 3.68, respectively), fenpropathrin $(\mathrm{SF}=3.37$ and 1.21, respectively), and gamma-cyhalothrin insecticides $(\mathrm{SF}=5.79$ and 10.48 , respectively). The same significance level was obtained when $1 / 4$ of the $\mathrm{LD}_{50}$ of the essential oil was combined with the beta-cypermethrin insecticide $(\mathrm{SF}=5.15)$ (Table 2).

The SF values of the PAEO and pyrethroid combinations evaluated were higher than those obtained by GIST \& PLESS (1985) when combining cypermethrin with PBO (SF between 1.31 and 3.1) and by BERNARD \& PHILOGÈNE (1993) when combining gamma-cyhalothrin $(\mathrm{SF}=3.5)$ with $\mathrm{PBO}$, as well. Such results revealed the synergistic efficacy of the PAEO for this contamination pathway and insecticide group, regardless of sub-dose used.

The significance of the comparison between the SF values of fenpropathrin and PBO $(\mathrm{SF}=4.21)$ was obtained within the confidence interval limits with a variation between 0.49 and 4.23. Piperonylbutoxide in combination with the synthetic pyrethroids evaluated exhibited relatively low SF values, ranging from 1.80 to 4.47. PBO acts in inhibiting the oxidases and esterases of $\boldsymbol{S}$. frugiperda larvae, decreasing the detoxification capacity and consequently increasing the lethality of pyrethroids to this insect (USMANI \& KNOWLES, 2001).

Angular coefficient values of the dosemortality curves were considered low for topical contact in both synergistic combinations of the PAEO with the four insecticides evaluated. These 
Table 1 - Chemical composition (\%) of the Piper aduncum L. essential oil used as synergistic insecticide of the synthetic pyrethroid chemical group.

\begin{tabular}{|c|c|c|c|}
\hline Chemical compounds & Percentage & Chemical compounds & Percentage \\
\hline$\alpha$-copaene & 0.1 & $(E)$ - $\beta$-ocimene & 0.1 \\
\hline$\alpha$-cadinol & 0.1 & Elemicin & 0.3 \\
\hline$\alpha$-phellandrene & 0.3 & epi-cubebol & 0.4 \\
\hline$\alpha$-humulene & 1.3 & Humulene epoxide-II & 0.4 \\
\hline$\alpha$-muurolol & 0.1 & $(E . E)$ - $\alpha$-farnesene & 0.4 \\
\hline$\alpha$-pinene & 1.8 & $\Omega$-terpinene & 1.1 \\
\hline$\alpha$-terpineol & 0.1 & $\gamma$-muurolene & 0.1 \\
\hline$\alpha$-terpinene & 0.3 & Germacrene D & 0.3 \\
\hline Alloaromadendrene & 0.3 & Limonene & 1.0 \\
\hline Apiol & 0.4 & Myrcene & 0.2 \\
\hline$\beta$-caryophyllene & 2.6 & Myristicin & 0.6 \\
\hline$\beta$-copaene & 0.1 & $\Omega$-cadinene & 0.3 \\
\hline$\beta$-cubebene & 0.1 & Caryophyllene oxide & 1.1 \\
\hline$\beta$-elemene & 0.3 & $p$-cymene & 0.4 \\
\hline$\beta$-ocimene & 0.2 & Perylene & 0.2 \\
\hline$\beta$-pinene & 1.5 & Pentadecane & 0.8 \\
\hline$\beta$-Santalene & 0.1 & Piperitone & 4.6 \\
\hline$\beta$-silenene & 0.2 & Terpinolene & 0.2 \\
\hline Cyclosativene & 0.2 & Trans-cadine-1(2), 4-diene & 0.1 \\
\hline Cubebol & 0.8 & Viridiflorol & 0.4 \\
\hline Dillapiole & 71.9 & 4-Terpineol & 1.3 \\
\hline$(E)-$ Nerolidol & 0.2 & Unidentified & 2.7 \\
\hline
\end{tabular}

values, however, were higher than the respective angular coefficients of the insecticides considered individually in the case of both alpha-cypermethrin $(1 / 2$ $\mathrm{LD}_{50}$ of the PAEO) and beta-cypermethrin (Table 2). Fenpropathrin and gamma-cyhalothrin insecticides, conversely, exhibited higher angular coefficients than those synergistic combinations with PAEO.

As a result of this response homogeneity, reduced selection pressure for this larval population's resistance is expected for the PAEO synergistic combinations with alpha-cypermethrin and betacypermethrin via topical contamination.

The effect occurred through residual contact, expressed by the $\mathrm{LC}_{50}$ of the synergistic combinations of the PAEO with the insecticides evaluated, and also indicated sufficient toxicity for promoting $\boldsymbol{S}$. frugiperda larval mortality (Table 2).

For this contamination pathway, there were significant SF values for the two PAEO sub-doses combinations with beta-cypermethrin (SF=9.05 for $1 / 2 \quad \mathrm{LC}_{50}$ PAEO and 0.5 for $1 / 4 \quad \mathrm{LC}_{50}$ PAEO) and fenpropathrin ( $\mathrm{SF}=34.05$ for $1 / 2 \mathrm{LC}_{50}$ PAEO and 49.77 for $1 / 4 \mathrm{LC}_{50}$ PAEO) (Table 2). The maximum SF value $(1,141.57)$ stands out and, was yielded by combination of $1 / 4$ of the $\mathrm{LC}_{50}$ of the PAEO with alpha-cypermethrin. A significant $\mathrm{SF}$ value was obtained for beta-cypermethrin combined with $1 / 2$ of the $\mathrm{LC}_{50}$ of the PAEO (9.10) compared with the value for PBO $(\mathrm{SF}=6.17)$, within the confidence interval limits ranging from 0.14 to 5.94 .

The SF values were insignificant for the synergistic combinations of the alpha-cypermethrin with $1 / 2$ of the $\mathrm{LC}_{50}$ of the PAEO and for the two synergistic PAEO combinations with gamma-cyhalothrin via residual contact. These results indicated synergistic inefficiency associated with this contamination pathway, since SF was significant for insecticides via the topical pathway, regardless of the proportion of PAEO used.

Contrary to what was expected, higher SF values were observed for the combinations of PAEO used at $1 / 4$ of the $\mathrm{LC}_{50}$ or $\mathrm{LD}_{50}$ and/or lethal doses than at half of the respective $\mathrm{LC}_{50}$ or $\mathrm{LD}_{50}$ for most of the insecticides via both contamination pathways evaluated (Table 2). Such results may be attributed to the responses to the different proportions of the PAEO combinations with the insecticides, which met the equivalence index that classified the combinations as additive, synergistic, or antagonistic (RAMAKRISHNAN \& JUSKO, 2001).

Angular coefficient values of the concentration-mortality curve were low for residual contact. However, the angular coefficients of the 
Table 2 - Toxicity of the PAEO combinations with synthetic pyrethroid insecticides Spodoptera frugiperda (J.E.Smith, 1797) larvae via topical and residual contact.

\begin{tabular}{|c|c|c|c|c|c|}
\hline $\begin{array}{l}\text { Insecticide } \\
\text { combinations }\end{array}$ & $\begin{array}{l}\mathrm{LD}_{50}\left(\mu \mathrm{L} \mathrm{mg} \mathrm{insect}{ }^{-1}\right) \text { and } \mathrm{LD}_{50} \\
\left.\quad(\mu \mathrm{L} \mathrm{cm})^{-2}\right)-(95 \% \mathrm{CI})\end{array}$ & SF & $\mathrm{N}$ & $\mathrm{HF}$ & Angular coefficient $+\mathrm{MSE}$ \\
\hline \multirow{2}{*}{ PAEO } & $1.2 \times 10^{-2}\left(7.1 \times 10^{-3}-1.8 \times 10^{-2}\right)$ & ----- & 280 & 1.31 & $0.33 \pm 0.04$ \\
\hline & $1.1 \times 10^{-4}\left(6.3 \times 10^{-5-} 1.6 \times 10^{-4}\right)$ & ------ & 160 & 1.69 & $0.52 \pm 0.04$ \\
\hline \multirow{2}{*}{$\alpha$-cypermethrin } & $1.9 \times 10^{-3}\left(1.2 \times 10^{-3-} 2.8 \times 10^{-3}\right)$ & ------ & 190 & 0.90 & $0.59 \pm 0.07$ \\
\hline & $1.6 \times 10^{-6}\left(1.2 \times 10^{-6}-1.9 \times 10^{-6}\right)$ & ----- & 200 & 0.77 & $0.38 \pm 0.02$ \\
\hline \multirow{2}{*}{$\begin{array}{l}\alpha \text {-cypermethrin }+ \\
1 / 2 \mathrm{LD}_{50 \mathrm{PAEO}}\end{array}$} & $7.9 \times 10^{-6}\left(2.8 \times 10^{-6}-1.5 \times 10^{-5}\right)$ & $7.6(7.5-7.9)^{*}$ & 200 & 0.92 & $0.65 \pm 0.09$ \\
\hline & $2.1 \times 10^{-7}\left(1.6 \times 10^{-7}-2.5 \times 10^{-7}\right)$ & $243.3(192.2-442.8)^{\mathrm{ns}}$ & 200 & 0.95 & $0.25 \pm 0.05$ \\
\hline \multirow{2}{*}{$\begin{array}{l}\alpha \text {-cypermethrin }+ \\
1 / 4 \mathrm{LD}_{50 \text { PAEO }}\end{array}$} & $1.7 \times 10^{-6}\left(1.3 \times 10^{-6}-2.2 \times 10^{-6}\right)$ & $3.7(3.4-3.7)^{*}$ & 220 & 1.32 & $0.57 \pm 0.06$ \\
\hline & $4.2 \times 10^{-7}\left(3.3 \times 10^{-7}-5.6 \times 10^{-7}\right)$ & $1141.6(969.9-1294.4)^{*}$ & 280 & 1.10 & $0.47 \pm 0.05$ \\
\hline \multirow{2}{*}{$\begin{array}{l}\alpha \text {-cypermethrin }+ \\
\text { BPO }\end{array}$} & $3.0 \times 10^{-6}\left(9.2 \times 10^{-7}-5.3 \times 10^{-6}\right)$ & $2.4(0.1-5.6)$ & 200 & 0.55 & $0.15 \pm 0.03$ \\
\hline & $6.5 \times 10^{-7}\left(2.2 \times 10^{-7}-1.4 \times 10^{-5}\right)$ & $638.1(533.7-1353.1)$ & 200 & 1.15 & $0.27 \pm 0.05$ \\
\hline \multirow[b]{2}{*}{$\beta$-cypermethrin } & $1.5 \times 10^{-2}\left(2.3 \times 10^{-4}-2.0 \times 10^{-2}\right)$ & 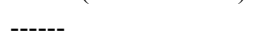 & 280 & 0.48 & $0.45 \pm 0.03$ \\
\hline & $1.5 \times 10^{-6}\left(1.2 \times 10^{-6}-1.9 \times 10^{-6}\right)$ & ----- & 240 & 1.52 & $0.52 \pm 0.07$ \\
\hline \multirow{2}{*}{$\begin{array}{l}\beta \text {-cypermethrin }+ \\
1 / 2 \text { LD }_{50 \mathrm{PAEO}}\end{array}$} & $1.7 \times 10^{-3}\left(1.0 \times 10^{-3}-2.7 \times 10^{-3}\right)$ & $1.0(0.8-1.0)^{\mathrm{ns}}$ & 200 & 0.96 & $0.62 \pm 0.03$ \\
\hline & $1.6 \times 10^{-6}\left(1.2 \times 10^{-6}-2.4 \times 10^{-6}\right)$ & $9.1(0.2-7.4)^{*}$ & 160 & 1.71 & $0.54 \pm 0.07$ \\
\hline \multirow{2}{*}{$\begin{array}{l}\beta \text {-cypermethrin }+ \\
1 / 4 \mathrm{LD}_{50 \mathrm{PAEO}}\end{array}$} & $2.8 \times 10^{-3}\left(2.0 \times 10^{-3}-3.7 \times 10^{-3}\right)$ & $5.2(5.2-5.3)^{*}$ & 200 & 0.35 & $0.67 \pm 0.04$ \\
\hline & $2.9 \times 10^{-7}\left(2.2 \times 10^{-7}-3.7 \times 10^{-7}\right)$ & $0.6(0.1-5.3)^{*}$ & 160 & 1.44 & $0.58 \pm 0.07$ \\
\hline \multirow{2}{*}{$\begin{array}{l}\beta \text {-cypermethrin }+ \\
\text { BPO }\end{array}$} & $2.5 \times 10^{-3}\left(1.7 \times 10^{-3}-3.3 \times 10^{-3}\right)$ & $4.5(4.4-4.5)$ & 200 & 0.29 & $0.56 \pm 0.07$ \\
\hline & $3.4 \times 10^{-7}\left(2.6 \times 10^{-7}-4.2 \times 10^{-7}\right)$ & $6.2(0.1-5.9)$ & 160 & 1.51 & $0.54 \pm 0.12$ \\
\hline \multirow{2}{*}{ Fenpropathrin } & $2.2 \times 10^{-3}\left(1.9 \times 10^{-3}-2.6 \times 10^{-3}\right)$ & ----- & 160 & 0.49 & $0.72 \pm 0.06$ \\
\hline & $6.2 \times 10^{-7}\left(4.0 \times 10^{-7}-8.4 \times 10^{-7}\right)$ & ------ & 230 & 0.80 & $0.59 \pm 0.08$ \\
\hline \multirow{2}{*}{$\begin{array}{l}\text { Fenpropathrin } \mathrm{F} \\
+1 / 2 \mathrm{LD}_{50 \mathrm{PAEO}}\end{array}$} & $6.4 \times 10^{-5}\left(3.6 \times 10^{-5}-9.5 \times 10^{-5}\right)$ & $3.4(2.7-3.8)^{*}$ & 200 & 1.11 & $0.50 \pm 0.09$ \\
\hline & $1.8 \times 10^{-7}\left(1.5 \times 10^{-7}-2.2 \times 10^{-7}\right)$ & $34.1(27.4-51.2)^{*}$ & 200 & 0.45 & $0.35 \pm 0.03$ \\
\hline \multirow{2}{*}{$\begin{array}{l}\text { Fenpropathrin }+ \\
1 / 4 \mathrm{LD}_{50 \mathrm{PAEO}}\end{array}$} & $4.4 \times 10^{-5}\left(2.1 \times 10^{-5}-6.8 \times 10^{-5}\right)$ & $1.2(1.1-1.1)^{*}$ & 200 & 1.38 & $0.67 \pm 0.09$ \\
\hline & $5.1 \times 10^{-7}\left(3.8 \times 10^{-7}-7.5 \times 10^{-7}\right)$ & $49.8(38.2-87.0)^{*}$ & 200 & 1.01 & $0.28 \pm 0.04$ \\
\hline \multirow{2}{*}{$\begin{array}{l}\text { Fenpropathrin }+ \\
\mathrm{BPO}\end{array}$} & $1.2 \times 10^{-4}\left(2.1 \times 10^{-5}-2.8 \times 10^{-4}\right)$ & $4.2(0.5-4.2)$ & 200 & 1.06 & $0.77 \pm 0.08$ \\
\hline & $1.5 \times 10^{-7}\left(1.2 \times 10^{-7}-1.7 \times 10^{-6}\right)$ & $17.9(9.0-90.3)$ & 160 & 1.70 & $0.43 \pm 0.08$ \\
\hline \multirow[b]{2}{*}{$\gamma$-cyhalothrin } & $1.1 \times 10^{-3}\left(8.5 \times 10^{-4}-1.4 \times 10^{-3}\right)$ & ------ & 200 & 1.09 & $0.86 \pm 0.07$ \\
\hline & $1.9 \times 10^{-7}\left(1.6 \times 10^{-7}-2.2 \times 10^{-7}\right)$ & ------ & 320 & 1.45 & $0.56 \pm 0.04$ \\
\hline \multirow{2}{*}{$\begin{array}{l}\gamma \text {-cyhalothrin } \\
1 / 2 \operatorname{LD}_{50 \mathrm{PAEO}}\end{array}$} & $\left.1.1 \times 10^{-4} 7.3 \times 10^{-5}-1.6 \times 10^{-4}\right)$ & $5.8(0.6-5.9)^{*}$ & 160 & 0.22 & $0.45 \pm 0.03$ \\
\hline & $3.3 \times 10^{-8}\left(2.7 \times 10^{-8}-3.8 \times 10^{-7}\right)$ & $9.7(8.5-11.7)^{\mathrm{ns}}$ & 280 & 1.38 & $0.40 \pm 0.04$ \\
\hline \multirow{2}{*}{$\begin{array}{l}\gamma \text {-cyhalothrin } \\
1 / 4 \mathrm{LD}_{50 \mathrm{PAEO}}\end{array}$} & $1.8 \times 10^{-4}\left(1.3 \times 10^{-4}-2.1 \times 10^{-4}\right)$ & $10.5(9.7-11.7)^{*}$ & 280 & 1.27 & $0.58 \pm 0.06$ \\
\hline & $1.8 \times 10^{-8}\left(1.4 \times 10^{-8}-2.3 \times 10^{-8}\right)$ & $6.2(6.3-6.5)^{\mathrm{ns}}$ & 200 & 1.54 & $0.54 \pm 0.10$ \\
\hline \multirow{2}{*}{$\begin{array}{l}\gamma \text {-cyhalothrin } \\
\text { BPO }\end{array}$} & $6.3 \times 10^{-5}\left(5.1 \times 10^{-5}-7.9 \times 10^{-5}\right)$ & $1.8(1.7-18.3)$ & 280 & 0.35 & $0.52 \pm 0.05$ \\
\hline & $1.8 \times 10^{-8}\left(1.6 \times 10^{-8}-2.1 \times 10^{-8}\right)$ & $17.1(16.8-17.3)$ & 320 & 0.90 & $0.49 \pm 0.04$ \\
\hline
\end{tabular}

Note: $\mathrm{LD}_{50}$ and $\mathrm{LC}_{50}=$ lethal doses and concentrations that cause $50 \%$ insect mortality; $95 \% \mathrm{CI}=$ confidence interval at $95 \%$ probability; and $\mathrm{SF}=$ synergism factors calculated as a function of lethal doses and concentrations. $(*)$ indicates significant difference between $\mathrm{SF}$ values of the combination and $\mathrm{BPO} ; \mathrm{N}=$ total number of insects to obtain the curve; $\mathrm{HF}=$ heterogeneity factor $(\mathrm{p}>0.1)$; and $\mathrm{MSE}=$ mean standard error.

insecticides considered individually for the alphacypermethrin $\left(1 / 4 \mathrm{LD}_{50}\right.$ PAEO $)$ and beta-cypermethrin $\left(1 / 2\right.$ and $1 / 4 \mathrm{LD}_{50}$ PAEO) combinations were even lower (Table 2).

As a result of this response homogeneity, corroborating previously obtained results for topical contact, reduced selection pressure for this larval population's resistance is expected for the synergistic combinations of PAEO with alpha- and beta-cypermethrin.
Prior to this study, the efficacy of dillapiole as a pyrethroid synergist had already been reported (WILKINSON et al., 1966; MUKERJEE et al., 1979; BERNARD et al., 1990). This secondary compound acts to detoxify insects through a combination of lignans with the methylenedioxyphenyl group, characteristic of Piperaceae and considered as a cytochrome P450 monooxygenase inhibitor.

As an additional tool for managing resistance to insecticides, PAEO has the potential 
to reduce commercial insecticide doses and PBO in particular (WALIA et al., 2004).

\section{CONCLUSION}

The efficacy of commercial insecticides such as beta-cypermethrin and fenpropathrin was significantly enhanced when combined with $\boldsymbol{P}$. aduncum essential oil via residual contact.

Only the alpha-cypermethrin, fenpropathrin, and gamma-cyhalothrin insecticides showed significantly enhanced efficacy via topical contact. The remaining insecticides, with the exception of fenpropathrin and gamma-cyhalothrin, exhibited response homogeneity for at least one synergistic combination with the $\boldsymbol{P}$. aduncum essential oil both via topical and residual contact.

Significance of the SF values of the combinations of PAEO with the alpha-cypermethrin, beta-cypermethrin, fenpropathrin, and gammacyhalothrin insecticides indicates a potential for this essential oil to be used as an alternative to PBO.

\section{ACKNOWLEDGEMENTS}

The authors thank Conselho Nacional de Desenvolvimento Científico e Tecnológico (CNPq) for granting scholarships

\section{REFERENCES}

ABBOTT, W.S. A method of computing the effectiveness of an insecticide. Journal of Economic Entomology, Riverside, v.18, n.2, p.265-267, Apr. 1925. Available from: <http://jee. oxfordjournals.org/content/18/2/265.2>. Accessed: Apr. 20, 2013. doi: $10.1093 /$ jee/18.2.265a

ADAMS, R.P. Identification of essential oil components by gas chromatography mass spectroscopy. Illinois: Allured Publishing Corporation, 1995. 456p.

AL-SARAR, A. et al. Impact of spray application methodology on the development of resistance to cypermethrin and spinosad by fall armyworm Spodoptera frugiperda (J.E. Smith). Pest Management Science, New Jersey, v.62, n.11, p.1023-1031, Nov. 2006. Available from: $<$ http://link.periodicos.capes.gov.br.ez103.periodicos.capes gov.br/sfxlc141?url ver=Z39.88-2004\&url ctx fmt=infofi/ fmt:kev:mtx:ctx \& ctx enc=info:ofi/enc:UTF-8\&ctx ver=Z39.88-2004\&rfr id=info:sid/sfxit.com:azlist\&sfx. ignore_date_threshold=1\&rft.object_id=958634688018>. Accessed: Aug. 12, 2014. doi: 10.1002/ps.1241.

BERNARD, C.; PHILOGENE, B.J.R. Insecticide synergists: role, importance, and perspectives. Journal of Toxicology and Environmental Health, United Kingdom, v.38, n.2, p.199233, 1993. Available from: <http:/www.tandfonline.com/doi/ abs/10.1080/15287399309531712\#.VeiTvZdcl14>. Accessed: Apr. 20, 2013. doi: 10.1080/15287399309531712.
BERNARD, C.B. et al. In vivo effect of mixtures of allelochemicals on the life cycle of the European corn borer, Ostrinia nubilalis. Entomologia Experimentalis et Applicata, New Jersey, v.57, n.1, p.17-22, Oct. 1990. Available from: <http://link.periodicos.capes.gov.br.ez103. periodicos.capes.gov.br/sfxlc141?url ver=Z39.88-2004\&url ctx fmt=infofi/fmt:kev:mtx:ctx\&ctx enc=info:ofi/ enc:UTF-8\&ctx_ver=Z39.88-2004\&rfr_id=info:sid/sfxit. com:azlist\&sfx.ignore date threshold=1\&rft.object id $=954925397456>$. Accessed: May 3, 2014. doi: 10.1111/ j.1570-7458.1990.tb01411.x.

BERNARD, C.B. et al. Insecticidal defenses of piperaceae from the neotropics. Journal of Chemical Ecology, Heidelberg, v.21, n.6, p.801-814, June 1995. Available from: <http://link.periodicos. capes.gov.br.ez103.periodicos.capes.gov.br/sfxlc141?url ver=Z39.88-2004\&url_ctx_fmt=infofi/fmt:kev:mtx:ctx\&ctx enc $=$ info: ofi/enc:UTF-8\&ctx ver $=Z 39.88-2004 \& \mathrm{rfr}$ id=info:sid/sfxit.com:azlist\&sfx.ignore_date_threshold=1\&rft. object id=954925466258>. Accessed: Jun. 12, 2014. doi: $10.1007 / \mathrm{BF} 02033462$

CASIDA, J.E. Mixed-function oxidase involvement in the biochemistry of insecticide synergists. Journal of Agricultural and Food Chemistry, Washington, DC, v.18, n.5, p.753-772, May 1970. Available from: <http://link.periodicos.capes.gov.br.ez103. periodicos.capes.gov.br/sfxlc141?url_ver=Z39.88-2004\&url_ctx_ $\mathrm{fmt}=$ infofi/fmt:kev:mtx:ctx\&ctx_enc=info:ofi/enc:UTF-8\&ctx ver $=$ Z39.88-2004\&rfr id=info:sid/sfxit.com:azlist\&sfx.ignore date threshold=1\&rft.object_id=954925410802>. Accessed: Jul. 18, 2014. doi: 10.1021/jf60171a013.

CHILCUTT, C.F.; TABASHINK, B.E. Evolution of pesticide resistance and slope of the concentration-mortality line: are they related? Journal of Economic Entomology, Riverside, v.88, n.1, p.11-20, Feb. 1995. Available from: <http://jee. oxfordjournals.org/content/88/1/11>. Accessed: Sep. 8, 2014. doi: $10.1093 /$ jee/88.1.11

CORZO, F.L. et al.Toxicity of Porella chilensis sesqui- and diterpenoids against larvae of the corn pest Spodoptera frugiperda (J.E. Smith) (Lepidoptera: Noctuidae). Neotropical Entomology, v.41, n.5, p.414419, Oct. 2012. Available from: <http://link.periodicos.capes.gov. br.ez103.periodicos.capes.gov.br/sfxlcl41?url ver=Z39.88-2004\&url ctx_fmt=infofi/fmt:kev:mtx:ctx\&ctx_enc=info:ofi/enc:UTF-8\&ctx_ ver=Z39.88-2004\&rfr id=info:sid/sfxit.com:azlist\&sfx.ignore date threshold=1\&rft.object ${ }_{-}$id $=991042728099630>$. Accessed: Oct. 13 , 2013. doi: 10.1007/s13744-012-0055-7.

FARNHAM, A.W. The mode of action of piperonyl butoxide with reference to studying pesticide resistance. In: JONES, D.G. (Ed.). Piperonyl Butoxide: the insecticide synergist. London: Academic, 1998. p.199-214.

FAZOLIN, M.et al. Potencialidades da pimenta-de-macaco (Piper aduncum L.): características gerais e resultados de pesquisa. Rio Branco: Embrapa- CPAF/AC, 2006. 53p. (Embrapa Acre. Documentos, 103). Available from: <http:// www.bdpa.cnptia.embrapa.br/consulta/busca $? \mathrm{~b}=\mathrm{ad} \& \mathrm{id}=5055$ $68 \&$ biblioteca $=$ CPAF-AC\&busca $=$ Potencialidades $\% 20 \mathrm{da} \% 20$ pimenta-de-macaco \&qFacets $=$ Potencialidades $\% 20 \mathrm{da} \% 20$ pimenta-de-macaco\&sort $=\&$ paginacao $=$ t $\&$ paginaAtual $=1>$. Accessed: Apr. 16, 2014

FINNEY, D.J. Probit analysis. London: Cambridge University, 1971. 33p.

Ciência Rural, v.46, n.3, mar, 2016. 
GIST, G.L.; PLESS, C. Synergistic activity of piperonil butoxide with nine synthetic piretroids against the fall armyworm, Spodoptera frugiperda. Florida Entomologist, Florida, v.68, n.2, p.316-320, June 1985. Available from: <http://journals.fcla.edu/ flaent/article/view/58019>. Accessed: Oct. 13, 2013.

GUEDES, R.N.et al. Sinergism of mineral oil in the insectide toxicity for Scrobipalpula absoluta (Lepidoptera: Gelechidae) Pesquisa Agropecuária Brasileira, Brasília, DF, v.30, n.3, p.313-318, Mar. 1995. Available from: <http://link.periodicos. capes.gov.br.ez103.periodicos.capes.gov.br/sfxlcl41?url ver=Z39.88-2004\&url_ctx_fmt=infofi/fmt:kev:mtx:ctx\&ctx_ enc $=$ info: ofi/enc:UTF- $8 \&$ ctx ver $=Z 39.88-2004 \&$ rfr id=info:sid/sfxit.com:azlist\&sfx.ignore_date_threshold=1\&rft. object_id=954925467283 > . Accessed: Oct. 2, 2014.

MAIA, J.G.S.et al.Constituents of the essential oil of Piper aduncum L. growing in the Amazon Region. Flavour and Fragrance Journal, New Jersey, v.13, n.4, p.269-272, July/Aug. 1998. Available from: $<$ http://link. periodicos.capes.gov.br.ez103.periodicos.capes.gov.br/sfxlc141?url ver $=$ Z39.88-2004\&url_ctx_fmt $=$ infofi/fmt:kev: $m t x: c t x \& c t x$ enc=info:ofi/enc:UTF-8\&ctx ver=Z39.88-2004\&rfr id=info:sid/ sfxit.com:azlist\&sfx.ignore_date_threshold $=1 \&$ rft.object id $=954925548311$. Accessed: Mar. 16, 2013. doi: 10.1002/(SICI)10991026(1998070)13:4<245::AID-FFJ736>3.0.CO;2-J.

MUKERJEE, S.K. et al. New methylenedioxyphenyl synergists for pyrethrins. Journal of the Agricultural and Food Chemistry, Washington, DC, v.27, n.6, p.1209-1211, Nov. 1979. Available from: <http://link.periodicos.capes.gov.br.ez103. periodicos.capes.gov.br/sfxlcl41?url_ver=Z39.88-2004\&url_ ctx_fmt=infofi/fmt:kev:mtx:ctx\&ctx_enc=info:ofi/enc:UTF8\&ctx_ver=Z39.88-2004\&rfr_id=info:sid/sfxit.com:azlist\&sfx. ignore_date_threshold $=1 \&$ rft.object_id $=954925410802>$. Accessed: Dec. 20, 2014. doi: 10.1021/jf60226a033.

PIMENTEL, F.A. et al. Processo de extração de óleo essencial de pimenta longa (Piperhispidinervum). Rio Branco: Embrapa Acre, 1998. 2p. (Embrapa Acre. Comunicado Técnico, 97). Available from: <http://www.bdpa.cnptia.embrapa.br/consulta/busca?b= ad\&id $=246524 \&$ biblioteca $=$ CPAF - AC\&busca $=$ Processo $\% 20$ de $\% 20$ extra $\%$ C3\%A $7 \%$ C3\%A3o $\% 20$ de $\% 20 \%$ C3\%B3leo $\% 20$ essencial $\% 20 \mathrm{de} \% 20$ pimenta $\% 20$ longa\&qFacets $=$ Processo $\% 20$ de $\% 20$ extra $\%$ C3\%A $7 \%$ C $3 \%$ A3o $\% 20$ de $\% 20 \%$ C3\%B3leo $\% 20$ essencial $\% 20 \mathrm{de} \% 20$ pimenta $\% 20$ longa\&sort=\&paginacao $=\mathrm{t} \& \mathrm{pa}$ ginaAtual=1>. Accessed: Apr. 18, 2015.

PIMENTEL, F.A.; SILVA, M.R. Da. Recomendações sobre processo de destilação comercial de biomassa triturada de pimenta longa (Piper hispidinervum). Rio Branco: Embrapa Acre, 2003.3p. (Comunicado Técnico, 123). Available from: $<$ http://www. bdpa.cnptia.embrapa.br/consulta/busca? $\mathrm{b}=\mathrm{ad} \& \mathrm{id}=492672 \&$ bibliote ca $=$ vazio\&busca $=$ Recomenda $\% \mathrm{C} 3 \% \mathrm{~A} 7 \% \mathrm{C} 3 \% \mathrm{~B} 5$ es $\% 20$ sobre $\% 20$ processo $\% 20 \mathrm{de} \% 20$ destila $\% \mathrm{C} 3 \% \mathrm{~A} 7 \% \mathrm{C} 3 \% \mathrm{~A} 3 \mathrm{o} \% 20$ comercial $\% 20$ de $\%$ 20biomassa $\% 20$ triturada $\% 20 \mathrm{de} \% 20$ pimenta $\%$ 20longa\&qFac ets $=$ Recomenda $\% \mathrm{C} 3 \% \mathrm{~A} 7 \% \mathrm{C} 3 \% \mathrm{~B} 5$ es $\% 20$ sobre $\% 20$ processo $\% 20$ de $\% 20$ destila $\%$ C3\%A7\%C3\%A3o $\% 20$ comercial $\% 20$ de $\% 20$ biomassa $\% 20$ triturada $\% 20 \mathrm{de} \% 20$ pimenta $\% 20$ longa\&sort=\&pagina cao $=t \&$ paginaAtual=1>. Accessed: Apr. 20, 2014.

RAMAKRISHNAN, R.; JUSKO, W.J. Interactions of aspirin and salicylic acid with prednisolone for inhibition of lymphocyte proliferation. International Immunopharmacology, Amsterdam, v.1, n.11, p.2035-2042, Oct. 2001. Available from: <http://link. periodicos.capes.gov.br.ez103.periodicos.capes.gov.br/sfxlc141?url ver $=$ Z39.88-2004\&url_ctx_fmt=infofi/fmt:kev:mtx:ctx\&ctx_
enc=info:ofi/enc:UTF-8\&ctx_ver=Z39.88-2004\&rfr_id=info:sid/ sfxit.com:azlist\&sfx.ignore date threshold $=1 \&$ rft.object id $=110985646834884>$. Accessed: Aug. 25, 2014. doi: 10.1016/ S1567-5769(01)00132-1.

ROCHA, S.F.R.; MING, L.C. Piper hispidinervum: a sustainable source of safrole. In: JANICK, J. (Ed.). Perspectives on new crops and news uses. Alexandria: ASHS, 1999. p.479-481.

SAS Institute. User's guide: Statistics, Version 8.2. 6.ed. Cary, 2001. 95p.

STEWART, D. The evaluation of synergistic action in the laboratory and field. In: JONES, D.G. (Ed.). Piperonyl Butoxide: the insecticide synergist. London: Academic,1998. p.173-198.

TOMAR, S.S. et al. Synthesis and synergistic activity of dillapiole based pyrethrum synergists. Journal of Agricultural and Food Chemistry, Washington, DC, v.27, n.3, p.547-550, May 1979. Available from: <http://link.periodicos.capes.gov.br.ez103. periodicos.capes.gov.br/sfxlc141?url_ver=Z39.88-2004\&url_ctx fmt=infofi/fmt:kev:mtx:ctx\&ctx_enc=info:ofi/enc:UTF-8\&ctx_ ver=Z39.88-2004\&rfr_id=info:sid/sfxit.com:azlist\&sfx.ignore date threshold $=1 \&$ rft.object $i d=954925410802>$. Accessed: Nov. 6, 2014. doi: 10.1021/jf60223a012.

THOMAZINI, M.; FRANCO, M.R.B. Methodology for analysis of volatile constituents of flavor. Boletim da Sociedade Brasileira de Ciência e Tecnologia de Alimentos, Campinas, v. 34, n.1, p.52-59, 2000.

USMANI, K.A.; KNOWLES, C.O. DEF sensitive esterases in homogenates of larval and adult Helicoverpa zea, Spodoptera frugiperda and Agrotis ipsilon (Lepidoptera: Noctuidae). Journal of Economic Entomology, Riverside, v. 94, n.4, p.884-891, Aug. 2001. Available from: <http://link.periodicos.capes.gov.br.ez103. periodicos.capes.gov.br/sfxlc141?url_ver=Z39.88-2004\&url_ctx_ $\mathrm{fmt}=$ infofi/fmt:kev:mtx:ctx\&ctx enc=info:ofi/enc:UTF-8\&ctx ver $=$ Z39.88-2004\&rfr_id=info:sid/sfxit.com:azlist\&sfx.ignore date threshold=1\&rft.object_id $=954925412870>$. Accessed: Apr. 20, 2014. doi: 10.1603/0022-0493-94.4.884.

WALIA, S.et al. Liquid chromatographic method for the analysis of two plant based insecticide synergists dillapiole and dihydrodillapiole. Journal of Chromatography A, Amsterdam, v.1047, n.2, p.229-233, Aug. 2004. Available from: <http://link.periodicos.capes.gov.br.ez103.periodicos. capes.gov.br/sfxlc141 ?url_ver=Z39.88-2004\&url ctx fmt=infofi/fmt:kev:mtx:ctx\&ctx enc=info:ofi/ enc:UTF-8\&ctx_ver=Z39.88-2004\&rfr_id=info:sid/sfxit. com:azlist\&sfx.ignore date threshold $=1 \& \mathrm{rft} . \mathrm{object}$ id $=954925411842>$. Accessed: Oct. 11, 2014. doi: $10.1016 / \bar{j}$. chroma.2004.07.009.

WILKINSON, C.et al. Structure and Synergism, some structural requirements of methylenodioxyphenyl derivates as synergists of carbamate insecticides. Journal of Agricultural and Food Chemistry, Washington, DC, v.14, n.1, p.73-79, Jan. 1966. Available from: <http:// link.periodicos.capes.gov.br.ez103.periodicos.capes.gov. br/sfxlc141?url_ver=Z39.88-2004\&url_ctx_fmt=infofi/ fmt:kev:mtx:ctx\&ctx enc=info:ofi/enc:UTF-8\&ctx ver=Z39.88-2004\&rfr_id=info:sid/sfxit.com:azlist\&sfx. ignore_date threshold $=1 \&$ rft.object_id $=954925410802>$. Accessed: Dec. 19, 2014. doi: 10.1021/jf60143a024. 